\title{
Questions and Instructions Found in Reading Sections Used in "Interlanguage: English for Senior High School Students XI" Textbook
}

\author{
Wonginsidi, O.D \\ English Department, Faculty of Languages and Literature, Petra Christian University, Siwalankerto 121-131, \\ Surabaya 60236, INDONESIA \\ E-mails: vinatropica@gmail.com
}

\begin{abstract}
This is a qualitative study of questions and instructions found in reading sections used in Interlanguage: English For Senior High School Students XI textbook. The writer observed the types of cognitive domains of questions and instructions and the key words found in the reading sections of the textbook. The data, consisting of questions and instructions, were collected from the reading sections of the first seven chapters of the textbook, as the source of data was from the textbook downloaded from the internet. In order to answer the research questions, she used the theory of Bloom's Revised Taxonomy as proposed by Anderson and Krathwohl (2001). The findings revealed the six types of cognitive domains of questions and instructions found in the reading sections of the textbook: remembering, understanding, applying, analyzing, evaluating, and creating and also revealing the key words of each cognitive domain of questions and instructions. Hopefully, this study can be of some help for other researchers who want to do the similar research on questions and instructions found in another textbook.
\end{abstract}

Keywords: Questions, Instructions, Cognitive Domains, Bloom's Revised Taxonomy

\section{INTRODUCTION}

In class, teachers ask some questions to students by using a textbook to check whether they have understood the materials to gain their knowledge, and to focus their minds. Also, teachers give some instructions to students by using a textbook in order to know students' knowledge and comprehension. Teachers use questions and instructions in a classroom to build an interaction with students in teaching and learning process. "Questions play an important role in the processes of teaching and learning because student's achievement and level of engagement depend on the types of questions formulated and used by teachers in the classroom" (Kerry, 2002, p.65). "Basically, teachers ask questions for a variety of purposes, including: to actively involve students in the lesson, to increase students' motivation and interest, to evaluate students' preparation, to develop critical thinking skill, and to review previous lesson" (Cotton, 1965, p.1). Students do not only get questions from teachers in the classroom, but also from the textbooks they use. There are some benefits of using textbooks. For teachers, "textbooks assist managing a lesson, it saves time, gives direction to lessons, guides discussion, facilitates in giving homework, makes teaching 'easier, better organized, more convenient', and most of all, it provides confidence and security" (The effective use of textbooks in the classroom, 2015). For students, "they see the textbooks as a 'framework' or 'guide', it helps them to organize their learning both inside and outside the classroom, and it enables them to learn "better, faster, clearer \& easier" (The effective use of textbooks in the classroom, 2015).

In this study, the writer chose Interlanguage: English for Senior High School Students XI textbook. This textbook has fifteen units. The reason why the writer chose this textbook was because this textbook is mainly used in several public senior high schools in Indonesia. In the textbooks, there are many kinds of questions and instructions available. By using the textbooks, students can learn and practice through the exercises provided in the textbook, published by "Pusat Perbukuan", Ministry of Education and Culture (Kemendikbud) in 2008 and written by Joko Priyana, Ph.D., Eka Denis Machfutra, and Zayin Adib Muhammad.

In this study, the writer focused on cognitive domains because each question and instruction found in textbooks has its own cognitive domains which aim to assess students' cognitive abilities. The purpose of cognitive aspects is oriented to thinking ability that includes simpler intellectual abilities, namely remembering, up to problem solving skills that require students to connect and 
combine several ideas, ideas, methods or procedures learned to solve those problems. Also, the writer only focused on the reading sections of this textbook because from the writer's point of view, questions and instructions in reading sections can help them to gain their knowledge of the lessons. Moreover, the writer chose the second grade of senior high school because students in that grade have understood some historical, art, economic, and cultural passages. They learn about those subjects at school and they are encouraged to read those kinds of passages.

The writer used the theory of Bloom's Revised Taxonomy proposed by Anderson and Krathwohl (2001) to analyze all questions and instructions in reading sections from unit 1 to unit 7 in this textbook because according to the learning implementation plan ("Rencana Pelaksanaan Pembelajaran"), the units discussed in class are from unit 1 to unit 7 during one semester. The writer focused on the six categories of cognitive domains of Bloom's Revised Taxonomy namely: Remembering, Understanding, Applying, Analyzing, Evaluating, and Creating" (Anderson and Krathwohl, 2001, p.214). According to Bloom (1956, p.7), "The cognitive domains includes goals which deal the recall and recognition of knowledge and development of intellectual abilities and skills".

To find out the cognitive domains of questions and instructions in the reading sections used in Interlanguage: English for Senior High School Students XI, the writer formulated the following research questions:

1. What are the types of cognitive domains of questions and instructions found in the reading sections of Interlanguage: English for Senior High School Students XI textbook?

2. What are the keywords of cognitive domains of questions and instructions found in the reading sections of Interlanguage: English for Senior High School Students XI textbook?

By conducting this study, the writer would like to find out the answers to the problems stated in the research questions. This study was to find out the types of cognitive domains of questions and instructions found in the reading sections used in the textbook. Moreover, the writer would like to find out the keywords of cognitive domains of questions and instructions found in the reading sections of the textbook.

\section{METHODS}

The writer used qualitative approach because (1) the instrument of this study was the writer herself, (2) the analysis was done with words, (3) this study was ultimately the product of the writer's subjective interpretation of the data. (Dörnyei, 2007)

\section{Data Collection and Data Analysis}

The data, consisting of questions and instructions, were collected from the reading sections of the first seven chapters of the textbook Interlanguage: English for Senior High School Students $\mathrm{XI}$, as the source of data for this study. The writer herself collected and analyzed the data based on the theories provided in chapter 2: the Importance of Questioning and Instructioning and Bloom's Revised Taxonomy as proposed by Anderson and Krathwohl (2001). The focus was on analyzing questions and instructions on reading sections from unit 1 to unit 7 in this English textbook.

In order to collect the data and answer the research questions, the writer applied some steps. First of all, the writer printed Interlanguage: English for Senior High School Students XI textbook which was already downloaded from the internet (http://library1.org/_ads/7D99BCA362DDAF5CAF88D1562A1013A9), and then, the writer read the textbook. After that, the writer identified all reading sections' questions and instructions from unit 1 to unit 7 in the textbook.

There would be two sub steps done. First, the writer chose only reading questions and instructions from the textbook and identified their forms. Second, the writer gave a numbering system. There were two digit numbers in numbering system: the first digit referred to the chapter in the textbook, and the second digit referred to each question and instruction of the chapter in the textbook.

In analyzing the data, the writer applied some steps. In the first step, the writer wrote down the questions and instructions on reading sections from the textbook which would be categorized into the cognitive domains in the following table. After that, the writer put the questions and instructions in data, the second column in table 3.1 below. 
Table 3.1 The Analysis of Questions and Instructions of Reading Sections

\begin{tabular}{|c|c|c|c|c|c|}
\hline No & Data & $\begin{array}{c}\text { Questions / } \\
\text { Instructions }\end{array}$ & Keywords & $\begin{array}{c}\text { Cognitive } \\
\text { Domains }\end{array}$ & Notes \\
\hline & & & & & \\
\hline & & & & & \\
\hline & & & & & \\
\hline
\end{tabular}

Abbreviations:
$\mathrm{R}=$ Remembering
Ap $=$ Applying
$\mathrm{E}=$ Evaluating
$\mathrm{U}=$ Understanding
An = Analyzing
$\mathrm{C}=$ Creating

The table was used to analyze the data. The table consisted of six columns which were numbers, data, questions / instructions, keywords, cognitive domains, and notes. The numbers columns would be used to give number for every question and instruction. In the data column, the writer wrote all questions and instructions of the textbook. In the questions / instructions column, the writer wrote an abbreviation for each question (Q) and instruction (I). Afterwards, in the keywords column, the writer identified the keywords of each question and instruction. Next, in the cognitive domains column, the writer identified the cognitive domains of each question and instruction. Lastly, the writer provided the explanation for the analysis in the notes column

\section{FINDINGS AND DISCUSSION}

Based on the analysis, the writer found out the types of cognitive domains of questions and instructions found in the reading sections and the keywords of cognitive domains of questions and instructions.

The Types of Cognitive Domains of Questions and Instructions Found in the Reading Sections

Based on the analysis done by the writer, there are six types of cognitive domains of questions found in the reading sections of the textbook: remembering, understanding, applying, analyzing, evaluating, and creating.

\section{Remembering}

Remembering is how students retrieve knowledge from long term memory. This domain is important for students because they have to remember what they have learned from the textbooks they use. Example of remembering related to questions:

1 . What is the celebration called?

This question belongs to remembering because the students have to retrieve the information from the text about the celebration that they have read so that they can answer the question.

\section{Understanding}

Understanding is how students construct meaning from instructional messages, including spoken, reported, and concrete conversation. This domain is important for students because they have to understand a lot of information. Example of understanding related to questions:

1. What is the meaning of the message in the poster?

This question above shows that the students have to understand the meaning of the message in the poster that they have read. Thus, this question belongs to understanding.

\section{Applying}

Applying is how students carry out or use a procedure in a given situation. This domain is important for students because they have to apply what they have done in a given situation. Example of applying related to questions:

1. Do you know how we can help stop global warming? 
This question above shows that the students have to apply the information they have read to stop global warming. They have to read some articles in the internet, newspaper, magazines, textbooks, or any other sources and after reading the articles, they have to answer the question. This question belongs to applying because they have to use a procedure in a given situation.

\section{Analyzing}

Analyzing is how students break material into its constituent components and determine how the components are linked to one another and to an overall structure or purpose. This domain is important for students because they have to analyze some information that they read from some texts or articles. Example of analyzing related to questions:

1. How should the proposal be followed up?

This question shows that the students have to break material into its constituent components. There is a reading text that they have to read and after reading the text, they have to answer the question. This question belongs to analyzing because they have to analyze how the proposal should be followed up.

\section{Evaluating}

Evaluating is how students make judgments based on criteria and standards. This domain is important for students because they have to evaluate their activities that they have done. Example of evaluating related to questions:

1. Should everyone participate in handling the problem?

This question shows that the students have to make judgments based on criteria and standards. There are some articles that they have to read in the internet, newspaper, magazines, textbooks, or any other sources and after reading the articles, they have to answer the question. This question belongs to evaluating because they have to decide whether everyone should participate in handling the problem.

\section{Creating}

Creating is how students put elements together to form a coherent or functional whole; reorganize elements into a new pattern or structure. This domain is important for students because they have to create something based on what they got from some information. Example of creating related to questions:

1. What is Retno's opinion on the action that should be done to reduce global warming?

This question shows that the students have to develop their ideas based on the information. There is a dialogue that the students have to read and after reading the dialogue, they have to answer the question. This question belongs to creating because they have to explain Retno's opinion on the action that should be done to reduce global warming.

\section{The types of cognitive domains of instructions found in the reading sections}

Based on the analysis done by the writer, there are six types of cognitive domains of instructions found in the reading sections of the textbook: remembering, understanding, applying, analyzing, evaluating, and creating.

\section{Remembering}

Example of remembering related to instructions:

1. Choose the correct answer to every question below based on the text in task 11 .

This instruction shows that the students have to retrieve the information from the text before choosing the correct answer to every question based on the text. Thus, it belongs to remembering.

\section{Understanding}

Example of understanding related to instructions:

1. In pairs, summarize the information that you learn from the dialogue below in

the following chart.

This instruction shows that the students have to understand the information that they learn from the dialogue first before summarizing it in the following chart. There is a dialogue that they have to read 
and after reading the dialogue, they have to understand first and then summarize the information from the dialogue. This instruction belongs to understanding because they have to build definition from the written message.

\section{Applying}

Example of applying related to instructions:

1. Work in pairs.

This instruction shows that the students have to apply what they have done in a given situation by working in pairs. Thus, it belongs to applying because working in pairs means they have to apply what they have to do in a given situation. There are some words/phrases with their meanings and they have to match each word/phrase with its meaning.

\section{Analyzing}

Example of analyzing related to instructions:

1. In groups of three, discuss what the poem is about.

This instruction shows that the students have to break material into its constituent components. There is a poem that they have to read and discuss, and then they have to analyze about the poem. This instruction belongs to analyzing because they have to analyze what the poem is about.

\section{Evaluating}

Examples of evaluating related to instructions:

1. Correct the false statements.

This instruction shows that the students have to make judgments based on criteria and standards. There is some information that they have to read and after reading the information, they have to correct the false statements. Moreover, this instruction belongs to evaluating because they have to evaluate the false statements to make them true.

\section{Creating}

Examples of creating related to instructions:

1. Rearrange the following jumbled paragraphs into a good report.

This instruction shows that the students have to reorganize elements into a new pattern or structure. There is a reading text that they have to read and after reading the text, they have to rearrange the following jumbled paragraphs into a good report. This instruction belongs to creating because they have to create the jumbled paragraphs into a good report.

\section{The keywords of cognitive domains of questions and instructions found in the reading sections}

The key words used in each cognitive domain related to questions and instructions can be summarized in the following table:

Table 4.2 The keywords of cognitive domains of questions and instructions

\begin{tabular}{|c|c|c|c|c|c|c|}
\hline $\begin{array}{l}\text { Cognitive } \\
\text { Domain } \\
\text { Instruction \& } \\
\text { Questions }\end{array}$ & $\mathrm{R}$ & $\mathrm{U}$ & Ap & An & $\mathrm{E}$ & $\mathrm{C}$ \\
\hline Instructions & $\begin{array}{l}\text { Choose } \\
\text { Complete } \\
\text { Answer } \\
\text { Retell } \\
\text { Use }\end{array}$ & $\begin{array}{c}\text { Summarize } \\
\text { Report } \\
\text { Read } \\
\text { Find } \\
\text { Study }\end{array}$ & $\begin{array}{l}\text { Use } \\
\text { Work } \\
\text { Act } \\
\text { Choose } \\
\text { Be }\end{array}$ & $\begin{array}{l}\text { Discuss } \\
\text { Compare } \\
\text { Include } \\
\text { Match }\end{array}$ & $\begin{array}{l}\text { Correct } \\
\text { Decide } \\
\text { Check } \\
\text { Guess }\end{array}$ & $\begin{array}{c}\text { Rewrite } \\
\text { Rearrange } \\
\text { Summarize } \\
\text { Write } \\
\text { Give }\end{array}$ \\
\hline
\end{tabular}




\begin{tabular}{|c|c|c|c|c|c|c|}
\hline & $\begin{array}{l}\text { Present } \\
\text { Include } \\
\text { Ask } \\
\text { Do } \\
\text { Mention } \\
\text { Add } \\
\text { Practise } \\
\text { Pay } \\
\text { attention } \\
\text { What } \\
\text { Where } \\
\text { When } \\
\text { How long } \\
\text { How }\end{array}$ & $\begin{array}{c}\text { Answer } \\
\text { Underline } \\
\text { Circle } \\
\text { Discuss } \\
\text { Complete } \\
\text { Put } \\
\text { Write }\end{array}$ & $\begin{array}{c}\text { Pay } \\
\text { attention } \\
\text { Read }\end{array}$ & & & $\begin{array}{c}\text { Opinion } \\
\text { Complete } \\
\text { Arrange } \\
\text { Make }\end{array}$ \\
\hline Questions & $\begin{array}{c}\text { What } \\
\text { Where } \\
\text { When } \\
\text { How } \\
\text { Who } \\
\text { Why } \\
\text { To whom } \\
\text { How much } \\
\text { Have } \\
\text { (Present } \\
\text { Perfect } \\
\text { Tense) } \\
\end{array}$ & What & $\begin{array}{l}\text { How } \\
\text { When }\end{array}$ & $\begin{array}{l}\text { Suggest } \\
\text { Reason } \\
\text { Argument } \\
\text { Opinion } \\
\text { How }\end{array}$ & Should & Opinion \\
\hline
\end{tabular}
R: Remembering
Ap: Applying
E: Evaluating
U: Understanding
An: Analyzing
C: Creating

The keywords of cognitive domains of instructions:

Remembering:

1. Choose

Example: Choose the correct answer to every question below based on the text in task 11 .

Understanding:

\section{Summarize}

Example: In pairs, summarize the information that you learn from the dialogue below in the following chart.

Applying:

1. Use

Example: You may use the dictionary.

Analyzing:

1. Discuss

Example: In groups of three discuss what the poem is about.

Evaluating:

1. Correct

Example: Correct the false statements. 
Creating:

1. Rewrite

Example: Rewrite the following jumbled paragraphs into a good report.

\section{The keywords of cognitive domains of questions:}

Remembering:

1. What

Example: What is the celebration called?

Understanding:

1. What

Examples: What does the picture in the poster try to show or say?

Applying:

1. How

Example: Do you know how we can help stop global warming?

Analyzing:

1. Suggest

Example: What does Helmi suggest that Retno should do?

Evaluating:

1. Should

Example: Should every one participate in handling the problem?

Creating:

1. Opinion

Example: What is Retno's opinion on the action that should be done to reduce global warming?

\section{CONCLUSION}

The purpose of the study was to find out the cognitive domains and the keywords of cognitive domains of questions and instructions found in the reading sections of Interlanguage: English for Senior High School Students XI textbook. The findings show that the types of cognitive domains of questions and instructions found in the reading sections of the textbook are remembering, understanding, applying, analyzing, evaluating, and creating. In the reading sections, all the cognitive domains are applied; because the students have to remember what they have read, they have to understand the information that have read, they have to apply some steps based on the information they have read, they have to analyze what they have read, they have to evaluate some statements based on the information they have read, and they have to create some opinions or arguments based on what they have read.

Also, the writer found out the keywords of cognitive domains of questions and instructions found in the reading sections of the textbook. Some keywords used in the questions and instructions are related to the cognitive domains in which the students have to remember what they have learned from some texts in the textbook, to understand some information based on their knowledge, to apply some procedures given based on the information, to analyze some information they have read, to evaluate some statements based on the information they have read, and to create some opinions or arguments based on what they have read.

Hopefully, this study can be of some help for other researchers who want to do the similar research on questions and instructions found in another textbook. 


\section{BIBLIOGRAPHY}

Anderson, L.W \& Krathwohl, D. R. (Eds.). (2001). A Taxonomy for learning, teaching and assessing: A Revision of Bloom's taxonomy of educational objective. New York: Longman.

Basic Education. The effective use of textbooks in the classroom. (n.d.). Retrieved June 2, 2018 from http://www.umalusi.org.za/docs/presentations/2015/textbooks.pdf.

Bloom, B. (1956). Taxonomy of Educational Objective: The Classification of educational goals, by a committee of college and university examiners (1st edition). New York: Longmans.

$\begin{array}{llll}\text { Bloom's } & \text { Taxonomy. } & \text { (n.d). } & \text { Retrieved }\end{array}$ http://www.bloomstaxonomy.org/Blooms\%20Taxonomy\%20questions.pf

Cotton, K. (1965). Monitoring Student Learning in the Classroom. Portland:Northwest Regional Education Laboratory.

Dörnyei, Z. (2007). Research Methods in Applied Linguistics: Quantitative, Qualitative, and Mixed Methodologies. Oxford: Oxford University Press.

Kerry, T. (2002). Explaining \& Questioning. Retrieved March 20, 2018 from https://books.google.co.id/books?hl=id\&lr=\&id=4wmaN9rPVVAC\&oi=fnd\&pg=PR4\& $\mathrm{q}=$ explaining+and+questioning+kerry+2002+cheltenham\&ots=S8I4eyqj6\&sig=yI5ZTT Lzv-

CqSBDLJoFwzwqhiI\&redir_esc=y\#v=onepage $\& \mathrm{q}=$ explaining $\% 20$ and $\% 0$ questioning $\%$ 20kerry\%202002\%20cheltenham\&f $=$ false

Oktaviani, Z \&Aminah, A. N. (2017). Pengadaan Buku Paket, Haruskah Melulu dari Dana BOS? Retrieved March $20, \quad 2018$ from http://www.republika.co.id/berita/pendidikan/eduaction/17/12/31/p1hwfz84pengadaan buku-paket-haruskah-melulu-dari-dana-bos.

Priyana, J, Muhammad, Z. A \&Machfutra, E.D. (2008). Interlanguage: English for Senior High School Students XI Language Study Programme. Jakarta: Pusat Perbukuan. Retrieved March 16, 2018 from http://library1.org/_ads/7D99BCA362DDAF5CAF88D1562A1013A9.

Sanggenafa, R. (2016). Cognitive domains found on speaking skill questions used in English language textbook. Retrieved April 13, 2018 from https://dewey.petra.ac.id/catalog/digital/preview?id=2094525.

Setiawan. B. (2014). Questions and instructions delivered by senior and junior English teachers at a private Senior High School in Sidoarjo. Retrieved April 13, 2018 from https://dewey.petra.ac.id/catalog/digital/preview?id=2071695. 